\title{
Civilisations
}

Revue internationale d'anthropologie et de sciences

humaines

42-2 | 1993

enQuete d'identité

\section{In Quest of Identity - An Introduction}

\section{Vintilă Mihăilescu}

URL : http://journals.openedition.org/civilisations/2261

DOI : $10.4000 /$ civilisations.2261

ISSN : 2032-0442

\section{Éditeur}

Institut de sociologie de l'Université Libre de Bruxelles

\section{Édition imprimée}

Date de publication : 1 décembre 1993

Pagination : 21-32

ISBN : 2-87263-108-9

ISSN : 0009-8140

\section{Référence électronique}

Vintilă Mihăilescu, «In Quest of Identity - An Introduction », Civilisations [En ligne], 42-2 I 1993, mis en ligne le 30 décembre 1996, consulté le 19 avril 2019. URL : http://journals.openedition.org/ civilisations/2261 ; DOI : 10.4000/civilisations.2261

Ce document a été généré automatiquement le 19 avril 2019

(C) Tous droits réservés 


\title{
In Quest of Identity - An Introduction
}

\author{
Vintilă Mihăilescu
}

1 At the time when we are trying to draft this introduction for the articles that compose this volume, an image of childhood comes back to our mind : a mean little dwarf called Rumpelstilchen is dancing in a forest around a fire while singing: "Ach wie gut dass niemand weiss. Dasich Rumpelstilchen heis" (Luckily, nobody knows that my name is Rumpelstilchen). This is a tale of the Grimm brothers in which all the power of the forest's small spirit remains in the fact that no one knows his real name. And the story ends when, hidden behind a tree, the hero hears Rumpelstilchen sing. The day after, he calls him by his name and thus triumphs over the dwarf.

2 To give a name, to be named ... The tale of the Grimm brothers is a story amongst others that illustrates the magic of the name. To have (to acquire) a name, to give a name - and even "to someone of all sorts of names" - has always constituted the ritual gestures of a power play. Power that one can consider of "ontological" order, the extent of which the game is part of human condition. Only God, the Big Anonymous. "The one who is what he is", is not submitted to that game of designation.

3 With such a concept in mind, one looks at these articles and asks oneself is identity has not become the family name of this era's Rumpelstilchen. Certainly a more "technical" and desenchanted term, identity designates the new "spirits of the place" which meddle the forces of power's new games (or even stakes). The tales of our childhood have become unrecognisable ...

4 One can therefore ask oneself, with Christian Bromberger, if identity has not become "a sort of melting pot, a universal can-opener which would enable ta scamp one's work while dispensing a detailed analysis of facts ?" And one can also ask one self if the use of identity is only stemmed from the will of the actors themselves or if the observers' (anthropologists included) discursive reasoning has not also contributed to creating this situation. Doesn't defining “objectively" identities come out to, in a certain way, designate them, give them a name? Isn't carrying out a study on identity a way of being in quest of identity? We have already observed this for ethnology : to speak about it, 
comes out to create a bit of it. "I do not know if you realize it. Mr. Rumpelstilchen. but what you are speaking about is of identity ..."

\section{The heritage of identity}

5 The problems of identity, mostly ethnie, tend to occupy the front scene of public opinion and of scientific problematics. Developped by the media and by a growing number of colloquiums, special series of magazines, interviews and professional events on all sorts of matters, discussions on indentity have acquired a dramatic and exceptional nature. In their turn, "suspicions" generated by these "excesses" (as Bromberger would say) only exaggerate the sensation of novelty and of originality related to the identitary phenomena. After all, one is taken so much by discussions, that one loses the notion of reality. So, in casting a "distant glance" on this "identitary complex", one is tempted to ask openly the question: what is in stake and why does one speak about it when one discusses about identity?

6 The articles gathered in this volume try to envisage all the answers to this question.

7 Firstly, Giulio Angioni tries in all serenity to have identity come into line, and tum it into the "banality" of a universal and basic awareness, far more anciant than its present flamboyant existence. Considering conscience in general, its intersubjectivity and, more specifically, the feeling of belonging, or what is called collective identity, remains "one of the most constituent and universal attitudes of human groups". Through the antithetical logic which underlies it and which opposes the "Me" to the "Other", through the territoriality that illustrates this opposition and the aggressivity that accompanies this territoriality, "identity brings us closer to the rest of what is called the animal reign". Besides, human ethnology is deploying great efforts to bring up more than one argument as regards the biologie al origin of "foreign production".

Even if such a far-fetching reasoning is not accepted, there is still the other "banality", this one being totally "anthropological", and of which all introductions of ethnology refer to ; it opposes since immemorable times "we, the human beings" to "them, the nonhuman beings". Marianne Mesnil and Assia Popova have closely observed this “ banality" amongst the "Walloons, the Welsh and other Valakians".

9 Thereby, one can trace, beyond the actual identitary language, a much more anciant problematic. The concept of identity is influenced by a human constituent phenomena which is experienced and perceived differently according to eras and cultures. But since we are confronted with identity in the ambit of agame. whose different expressions are certainly historicized but whose rules are practically immutable, why then is there all this turmoil around identity? Why are surprising and decisive novelties given priority? Why is there all this movement between "excess and suspicions", between exaltation and anguish?

\section{Identity and raging toothache}

Behind the scenes of one of these numerous conferences on identity, someone was commenting as follows : "identity is like a tooth; one only thinks about it when it hurts". Joking apart, it is undoubtly true that one does not ask as many questions on one's "identity" as long as one is merged in the "routine of existing", as long as one can live in peace and be 
happy to simply live. It is only at a time when this carefree routine staggers for a reason or another that identitary anxieties appear.

Confronted with the upsurge of the actual identitary discursive reasoning and daims, one should therefore raise the question about the "frenzy" that seems to have invaded mankind today.

It is somehow in this perspective that François Laplantine manages to consider "these different movements of identitary protests as processes of "reactional demodemisation". Beyond the term of "demodernisation" - maybe arguable - what still remains, is the project of modemity's global crisis and the identitary reactions related to the latter.

The "end of ideologies" seems to be, after all that has been written on the matter, an accomplished fact. The recent collapse of communism is hence just the final dramatic point of a process of longer date which eroded the big systems of reference which a majority of people took as an example for their life "routine". More particularly, the opposition between communism and capitalism has played the role of an identitary lullaby, by offering a revised and corrected representation of the perpetuate opposition between "we, the human being" and "them, the non-human beings". (As regards the mythological analysis of Mesnil and Popova, the citizens of the Eastern countries will no doubt remember to what extent the Western countries' young people's long hair was presented as the expression of de cadence itself, or even of the state of "barbarism" of the West and how we struggled to prove our civility through the autochtones' strict discipline!) This division had the advantage of being simple, within reach, general (the Third World being a "integrated third", whether one likes it or not, in the confrontation of the two blocs) and reversible (each one could chose freely the "good" side and the " bad" side). In brief, providing that one would not be too demanding (and that one would not be its victim !), that conflict could offer minimal "identitary" references for everyone. All the more since the system also proposed conditions of existence to identities dreaming of refusing the "me different from others".

The collapse of communism - and by the same means, of the world's separation in two - is the last event in date of the world's longer term process of disenchantment (in fact, although atheist, communism was nonetheless a universal belief). The crisis, which is reaching its peak only now, is defined by two essential traits : it is globaland it is a crisis of faith(which does not necessarily mean that it is a religion crisis). According to that point of view, an important part of the phenomena, said to be "particularist", in fact only consists of reactions to that global crisis of belief which tries to find global answers to the desenchantment of the world. It is the diversity of such phenomenas on the one hand, and their "dissidence" compared to the dominant universalist project on the other hand, that make us be mistaken on their universalistic or, in any case, globalising vocation. As regards what is called - improperly, according to François Laplantine - "the retum of religion". "It is a question of making a distinction in relation ta the rest of humanity".

If one analyses it closer, it is not identity as such that is attractive or frightening, but rather its signification "hic" and "nunc". The development of identity takes place at a time when the universalist project of Reason was thought to exp and through its worldwide application. It is at that precise time that its uniformising pressure reaches its peak and becomes "perceivable", that its force plays a determining role for all who, for a reason or another, do not feel at ease in the part of the "universal man". For those people, it is now or never that they should react. Thus, the identitary "disuniversalist" exaltation. 
16 Moreover, it is at that precise time that the stake becomes essential for all the partisans of the Big Project. Now is the time when the destiny of the superb civilizing utopia of the two last centuries is being cast. Thus the refusal from the "universalists" toaccept these identitary expressions that constitute as many slaps in the face of Reason.

\section{Identify identities and differenciate differences}

In the way things are going, reality and discursive reasoning often intermingle into a disconcerting "panidentersim". Nevertheless, not every social or cultural part of existence is systematically "identitary". One does not bury one's dead with an " identitary" objective! It is only when one notices that they are not buried like others, when that difference corresponds to a factor of differenciation and when an intentional reasoning is expressed on the particularities related to the funeral, that funerals can become an "identitary mark". What remains to be determined is why funerals have been chosen as an identitary sign and why, generally, such signs are needed. The development of such an identitary discursive reasoning is in great part due to the confusion between these different levels of social existence which makes everything liable of being treated as an identitary phenomena. In this conceptual darkness, all identities are black...

Confronted with this conceptual skid, the different authors of this volume have felt the need ta define the level of identity's existence in itself, toidentity what is and what is not identity or the different types of identity. It is necessary to make a distinction more often between the level of social structure, behavioural practices, empiric characteristics of one's "me", on the one hand, and the level of presentation of one's "me", the discursive reasoning or the image that one has of basic reality, on the other hand; distinction between "interactional identity" and "ideological identity"made by Imre Eros, between "belonging"and "reference"by Pierre Centlivres between "performative identity"by Christian Bromberger, etc. And everyone - or almost - likes to discover the gaps between the two levels, the differences between experienced identity and related identity, the "collective conversions" which make the identitary image of one same social reality change according to the circumstances.

On the same line of idea of this first assessment. one can - and one must - go further. Indeed, as "interactional identity"(to use I. Eros's terminology as a reference) is submitted to several of interactions, so is "ideological identity"todifferent ideologies. The studies presented in this volume attest largely this fact. Firstly, there are structurally and objectively different interactional contexts: the relational tissue is not the same in a situation of nomadism, in the diasporas or in compact autochtonous communities. The other, the foreigner, does not have the same status when one goes from one foreigner ta the other along the paths of transhumance, when one receives the foreigner at one's home and when one goes to settle down at the other's home.

In her report on the Aroumains, Irina Nicolau gives us an exemplary account: this population (essentially shepherds and later traders disseminated throughout the Balkanic states) uses no less than 65 ethonyms! (names derived from toponyms not included). How can one live in such an "identitary" ambiguity ? - the author asks. When one looks closer, ambiguity disappears in order to give way to an adaptable but coherent logic. The 65 ethonyms are not used at any moment or time. In facto they are not synonyms but define different relational dualities: "the Greeks call us Kulovlahi, the Aroumains from Greece 
Viryareni, the Bulgarians Vlasi, the Aroumains farsirot Cipani, the Roumanians of Roumania Machedoni. Nobody knows that we are Gr'mu(teani' - declares an elder person of 80 years. And Rumpelstilchen, do you remember?

21 Less spectacular, but all the more typical is the case of the Roumanian village community : it gives us the example ofa relations between "we" and the "others", which, according to E. Popescu“does not form a dearbinay opposition between good/bad, beneficial/ malefic, true/wrong. The compensatory system applied by traditional mentality euphemises these relations in order to control them better:unknown/recognisable, contaminated/curable, dangerous/tameable". The "other" does not have the absolute and exclusive character of the antithesis "us" - "the others". Together, "us" and "the other" form a constituent relational matrix whereby the foreigner is never total or definitive and the autochtone is always positional. T. Guéorguiéva gives us an example of similar relations and negociations between Bulgarians, Turcs and Pomaks of the Rodopes, that often dramatic identitary conflicts do not spare all the same.

A more general form of "interactional identity", other than the particular examples, seems to appear. It is tempting to call it relationism. It gives a priority to community relations compared to individual terms in relations ; it supposes a social legislation (a ritualisation in this case) which concerns rather relations between people than "rights and obligations" of individuals as such. In brief, one can say that in the case of "relationism", it is the relation that creates and defines the se terms and not the terms that create a relation. In this last case, it is preferable to speak of essentialism, because the terms of the relations are related to individual factors that interact "afterwards" ${ }^{\text {. Essentialism, which }}$ is typical of our individualist societies and of our mental habits of "clear" catagorisation, supposes a behavioural logic different from the one of relationalism, more laxist.

Without developing further here such an analysis, even go a minimal methodological prudence seems to suggest a somewhat nuanced use of common catagories such as "us and the others", "foreigner", "xenophobia", etc., that do not systematically have the same scope and the same signifiance in the two contexts which have just been differenciated.

24 A similar differenciation (but not synonymous) is necessary for "ideological identity". Louis Dumont suggests this at the beginning of his book on German ideology with this constrastive observation: "I have contrasted the French as follows : "I am a man by nature and French by accident" and the German : "I am fundamentally German, and l am a man thanks to my quality as German". ( ... ) It is obvious that if these two men are talking about the diversity of cultures, they do not have the same opinion, they are not speaking on the same level: the German man speaks about the essential, the French about contrasted, but secondary diversities" (Dumont, 1992).

\section{Identity between spirit and appearance}

For obvious historical reasons, "German ideology" of identity if often frightening. Appearance-identity is easily prefered tospiritidentity; the critical analysis of the actual identitary phenomena speaks more about identity "which is created" than identity which "is". Rose-Marie Lagrave - can be considered, by simplitying, as a synthesis of the French 
more universalist ideology the American mode interactionist methodology. As an approach, it is an efficient and subtle instrument that enables to demonstrate the exalted pretentions of all the "We, the Thraces", "We, the Celtic" and other identities. These more or less tacit presuppositions can be summarized as follows : if there is identity, it is one and universdal, that of human nature or simply of the human ; everything that is "below" is the result of a particular interactional context and remains particular and secondary. On the contrary, "production" as such is carried out by universal mecanisms: the production of one self and/ or of the other would therefore be the invariable factor of "identitary differences". And it is this invariability which is essential and which should be sought.

Although subtle and fecund, nonetheless this "constructivist" approach raises problems. The first question that can be brought up is to know if the "production of identity" is submitted to the same rules whatever the historical and cultural, if the conceptual and methodological transformation from the one situation to the other is licit or not.

Another problem is raised, more or less indirectly, by Christian Bromberger : "if the locating, the production, the assertion, the perception of identities have become the subject of numerous punctual studies, ethnology in France has, on the other hand and paradoxically, analysed a lot less the social effects generated by the conscience of a common belonging". Identities have been examined "in their origin, through their organisation - in their actual state, through the echo of their resonance in the short term and the long term". Does the fact of giving oneself a "perfomative" identity, which extends beyond "subtantial" identity, remain without marketing "substantial" identity itself? Is the identity "created" exterior to the "structural characteristics of phenomenas" ? To paraphrase Kundera, this would lead us to an "unbearable lightness of identity". However, this identity stays indisputably "heavy", this being somewhat related to belief. The belief of being someone else ...

An essential question is raised openly by Cecile Zervoudacki : the reason of all history. "Ethnicity is not, indeed, a social ressource like others". Therefore, it cannot be send to the communal grave. It is necessary ta seek its reason of existence "in its origin", maybe even further behind than the author thinks. It is necessary ta retrace the role of ethnologists from being reduced to that of a Zorro denouncing impostures" (Bromberger ).

\section{Manipulation and kitsch}

"... The need of identity, if abstract is nonetheless tangible. The need of roots in a local society has not disappeared"- declare the mayors of big suburbs of Provence in an official report published in 1985 (quoted by Morel). The unasiness expressed by elected councillors is obvious; what seems more doubtful is the recommended treatment. "Elected councillors make the settling of populations a key element of their policy. But, how can one "settle" populations if they have not taken root? ( ... ) The complex phenomena of settlement which implies duration, jusional relations, interknowledge. etc... is reduced to one of its characteristics: the feeling of belonging toa place". Therefore, doens't the stake reside in "inventing new forms of social solidarity coherent with the dominant logic of society?" (Morel)

31 The answer that Andreas Bimmer gives to that question is unequivocal : the modern feasts organised by municipalities in order to "settle" their populations make us think of 
the "political folklore" rather than the notion of feast. "... Spacial and regional factors no longer dejine theformation ofidentity. As for modemfeasts, they are no longer sufficient to found a new identity". The analysis of one of these feasts (the Hessentag) is an example.

On another scale, Zoltan Biro and Julianna Bodo have observed the voluntarist construobserved the voluntarist creation of a regional identity, of a "feeling of belonging to a place" in the case of a newly created region in Roumania: the Harghita. This "production of identity" includes almost all the formai elements of a creation of identity in general. However, "harghiteanism" does not develop and people are not able to "take roots" in the administrative zone that is proposed to them as theirs. This does not prevent "political folklore" from carrying along.

33 A more classic example is givin by Zusana Stefanikova who analyses the identitary creation of the Slovac "national costume" and its anti-Hungarian "reactive" fluctuations dating from the Habsbourg era. its anti-German period during the Third Reich. etc. This example is not only more "classic" but also different, from the fact that the "national costume" kept a permanent referent through the "folkloric costume", recognised and shared by the community as being theirs "from the beginning". And it is precisely that difference that enables us to foresee a fundamental gap in the recent indetitary manipulations.

The need to incorporate history, a more or less mythicised pasto although shared by the community, is an essential component of identity. The "success" of the Greek community of Pont-de-Cheruy described by Cecile Zervoudacki seems to entail the creation and the acceptance of an ad-hoc "founding myth".

Different factors seem to suggest that the "horizontal" reference functional and synchronie, of identity is not sufficient for the human being. A fundamental need brings us to find references beyond the limits of our existence "hic" and "nunc"."Vertical" references drawn from the past in arder ta transform them into a gift in the form of beliefs, seem to be unavoidable. To stay a human being, one ismore than one lives.

However, it is precisely these "fibers of diacrony", these "vertical references" which have systemically been atrophied by modernity, concentrated by definition on the present. Besides real uprootings on a geographical level (emigration, etc.) and/or on a time level (passage of a "traditional" society to a form of industrial society), modernity has also created a general state of uprootingwith the worldwide application of values of the present and of its "superficial" activities. If one accepts to call beliefthis vertical proclivity of identity, it comes out to be, in short, the theme of the "world's desenchantment", the problem of the so-called "return to religion" and the explanation to the usual failures in attempts to "settle" : torn up, the "fibers of diacrony" have problems in reconstitating themselves.

Patrimony has constituted the main therapy that authorities as well as local power have thought of finding as a solution to that "state of uprooting". The retum of historicity began. according to Edgar Morin. in the sixties with a "gap in the adhesion to the present"(quoted by Morel). Communities in distress tried to recreate their social relations, reinforce them, and give them more stability and personality. Not being able to find real means and maintain relations that they had developped, people have turned more and more towards objects that surrounded them. Human solidarity was that way related to the "categories" and "systems" of objects and history related to their age. Because of the lack of settlement, "which implies duration, fusional relations, interknowledge, etc.", 
individuals tried to create relations through the means of objects: their collective identity was created - and weakened - by the common reference to a category of patrimonial objects. And, according to this logic, everything could become a patrimonial object... to be consumed afterwards according to the customs of the consumer society. What was supposed to be an outlet turns out to be an abyss.

The reaction to modernity and its loss in human relations ${ }^{2}$ transform the hum an being into a "patrimonial animal" which is represented through objectivized forms - or even as simple objects - which are "devoured" after.

Is this deformed "anthropophagy" peculiar to kitsch? An extistencial kitsch, the kitsch of our existence ...

\section{NOTES}

1. Regarding that point of view, the famous American mode interactionism concerns the relations between terms that primarily been separated and individualised. Interactions are therefore weak relations, because secondary, somehow derived of the "essentialist" nature of their terms.

2. "The loss of uman relations (spontaneous. reciprocical. symbolic) is an essential trait of our societies. On this basis. one can observe the systematic reintroduction of hurnan relations in the form of signs in the social circuit and the "consommation" of these relations. of this signified heat". (Baudrillard. 1970-76).

\section{INDEX}

Mots-clés : identité, kitsch, politiques identitaires, essentialisme

Keywords : identity, kitsch, identity politics, essentialism

\section{AUTEUR}

VINTILĂ MIHĂILESCU

University of Bucarest 